International Journal of Canadian Studies

Revue internationale d'études canadiennes

INTERNATIONAL JOURNAL OF CANADIAN STUDIES

REYUE INTERNATIONALE D'ÉTUDES CANADIENNES

\title{
The Impact of the Charter: Untangling the Effects of Institutional Change
}

\section{Miriam Smith}

Numéro 36, 2007

Democracy, Rule of Law and Human Rights. Canada 25 Years after the Charter of Rights and Freedoms

La démocratie, l’État de droit et les droits de la personne. Le Canada, 25 ans après la Charte des droits et libertés

URI : https://id.erudit.org/iderudit/040775ar

DOI : https://doi.org/10.7202/040775ar

Aller au sommaire du numéro

\section{Éditeur(s)}

Conseil international d'études canadiennes

\section{ISSN}

1180-3991 (imprimé)

1923-5291 (numérique)

Découvrir la revue

\section{Citer cet article}

Smith, M. (2007). The Impact of the Charter: Untangling the Effects of Institutional Change. International Journal of Canadian Studies / Revue internationale d'études canadiennes, (36), 17-40.

https://doi.org/10.7202/040775ar
Résumé de l'article

Cet article présente un aperçu des principaux débats qui ont eu lieu sur l'incidence de l'enchâssement de la Charte dans la Constitution canadienne. Il ratisse large, car l'auteure y procède à un examen sélectif de l'impact de la Charte dans trois domaines principaux : 1) la politique publique; 2) les institutions politiques; 3) la mobilisation politique. L'auteure soutient que nous devrions cesser de considérer la Charte comme un document constitutionnel qui énonce les droits protégés par les tribunaux et la voir comme une influence structurante sur le débat politique canadien. Sur le plan des politiques, le document examine l'incidence instrumentale de la Charte sur le droit pénal et les droits des gais et lesbiennes. Bien que la Charte ait accru l'importance du pouvoir judiciaire par rapport aux autres institutions politiques, les effets discursifs et instrumentaux de la Charte se font également sentir sur les autres institutions politiques comme le pouvoir exécutif et le Parlement ainsi que sur le fonctionnement du fédéralisme. Ce qui est peut-être encore plus important, la Charte est devenue un facteur important de structuration de la mobilisation et du débat politiques, qui encourage les organismes de la société civile à faire valoir leurs revendications politiques en fonction des droits conférés par la Charte (pour le meilleur ou pour le pire) et qui contribue à la concurrence partisane entre les partis politiques fédéraux.
Tous droits réservés @ Conseil international d'études canadiennes, 2007
Ce document est protégé par la loi sur le droit d'auteur. L’utilisation des services d'Érudit (y compris la reproduction) est assujettie à sa politique d'utilisation que vous pouvez consulter en ligne.

https://apropos.erudit.org/fr/usagers/politique-dutilisation/ 


\title{
Miriam Smith
}

\section{The Impact of the Charter: Untangling the Effects of Institutional Change 1}

\begin{abstract}
This article provides an overview of the main debates on the impact of the Charter's entrenchment in Canadian politics. In doing so, it casts a wide net, providing a selective exploration of the impact of the Charter in three main areas: 1) public policy; 2) political institutions and 3) political mobilization. The paper argues that we should move away from thinking about the Charter as a constitutional document that sets out rights that are protected by courts and move towards a view of the Charter as a structuring influence on Canadian political debate. In policy terms, the paper examines the instrumental impact of the Charter on criminal law and on lesbian and gay rights. While the Charter has strengthened the hand of the judiciary relative to other political institutions, the discursive and instrumental effects of the Charter are also felt in other political institutions such as the executive and Parliament as well as the operation of federalism. Perhaps most importantly, the Charter has become an important factor in structuring political mobilization and debate, encouraging civil society organizations to stake their political claims in terms of Charter rights (for better or ill) and contributing to the partisan competition between political parties in federal politics.
\end{abstract}

\section{Résumé}

Cet article présente un aperçu des principaux débats qui ont eu lieu sur l'incidence de l'enchâssement de la Charte dans la Constitution canadienne. Il ratisse large, car l'auteure y procède à un examen sélectif de l'impact de la Charte dans trois domaines principaux : 1) la politique publique; 2) les institutions politiques; 3) la mobilisation politique. L'auteure soutient que nous devrions cesser de considérer la Charte comme un document constitutionnel qui énonce les droits protégés par les tribunaux et la voir comme une influence structurante sur le débat politique canadien. Sur le plan des politiques, le document examine l'incidence instrumentale de la Charte sur le droit pénal et les droits des gais et lesbiennes. Bien que la Charte ait accru l'importance du pouvoir judiciaire par rapport aux autres institutions politiques, les effets discursifs et instrumentaux de la Charte se font également sentir sur les autres institutions politiques comme le pouvoir exécutif et le Parlement ainsi que sur le fonctionnement du fédéralisme. Ce qui est peut-être encore plus important, la Charte est devenue un facteur important de structuration de la mobilisation et du débat politiques, qui encourage les organismes de la société civile à faire valoir leurs revendications politiques en fonction des droits conférés par la Charte (pour le meilleur ou pour le pire) et qui contribue à la concurrence partisane entre les partis politiques fédéraux. 


\section{Introduction}

Rights have become increasingly important in liberal democracies since World War II. It has become commonplace to assert that, like other countries, Canada has undergone a "rights revolution"2 in which, increasingly, political claims are discursively defined and constructed in terms of rights. Since the 1960 s, a wave of social movement activists and political actors, including the women's movement, the lesbian and gay movement, the Quebec and Aboriginal nationalist movements, and movements representing ethnocultural communities, have put forth claims in Canadian politics that are based on assertions of rights, whether national rights, collective rights, or individual rights. This article explores this contemporary move toward human rights by providing a selective overview of the impact of the entrenchment of a constitutional bill of rights in the Canadian Constitution - the Canadian Charter of Rights and Freedoms - on public policy, political institutions, and political mobilization.

Unlike the anemic Bill of Rights that preceded it, the Charter has turned out to be a muscular document, one that has exerted important and complex effects on Canadian politics, effects that we are only now beginning to discern, twenty-five years after its enactment. The move toward the constitutional entrenchment of individual and collective rights and the empowerment of courts as the institutional mechanism for enforcing and protecting such rights has occurred over the same period in other democracies as well. This international trend toward what political scientist Ran Hirschl has called "judicial empowerment" 3 has increasingly created a space for judicialized and legalized politics.

This article provides an overview of the main debates on the impact of the Charter's entrenchment in Canadian politics. In doing so, it casts a wide net, providing a selective exploration of the impact of the Charter on public policy, political institutions, and political mobilization. I argue that we should move away from thinking about the Charter as a constitutional document that sets out rights that are protected by courts and move towards a view of the Charter as a structuring influence on Canadian political debate. The article builds on the insights of the new historical work on the evolution of human rights in Canada, which clearly shows the evolution of political and social support for stronger human rights ${ }^{4}$ protections in Canadian society from the 1920 s to the 1960 s. From a historical perspective, debates on the Charter may be viewed as the continuation of earlier struggles over human rights, such as the campaign by Chinese Canadians and their allies for the repeal of the immigration ban in the 1920s; the campaign by Jewish labour organizers in Toronto and Montreal in the 1930s and 1940s against racism and fascism; the campaign by African Canadians against segregation in public facilities; the campaign by Japanese Canadians and their allies against internment, deportation, and forced internal migration; the campaign by church organizations and 
intellectuals for civil liberties in the 1930s and 1940s; and the campaign by women's organizations in Ontario for equal pay for equal work in the 1950 s. ${ }^{5}$ This important new research shows the ways in which human rights became intimately woven into Canadian political institutions and political discourse over time. In keeping with the temperament of recent historical scholarship, the article shows the intertwining of institutions, policy, and politics in the making of the new human rights regime in Canada. The article is divided into three main sections which discuss the Charter's effects in each of these areas: public policy, political institutions, and political mobilization.

\section{The Effect of the Charter on Public Policy}

The Charter has had a significant impact on the evolution of public policy since its entrenchment, altering the policy process and shaping policy in a number of areas. The Charter has been interpreted by the courts in ways that have produced certain substantive policy outcomes that might not have otherwise been produced or, if they had been produced, might have taken a different form or might have taken longer to enact. Nonetheless, the Charter's impact lies not only in its direct instrumental impacts on policy - that is, on the way in which courts require that governments alter their policies and procedure to conform to the Charter-but also in the discursive effects of changing public policy by means of the decisions of the Supreme Court of Canada. I will explore these two types of policy effectsinstrumental and discursive-through the discussion of two of the most important areas of substantive policy change under the Charter, namely, changes in the area of criminal law and changes in the area of equality rights for lesbians and gay men and same-sex couples.

The area of criminal law has been one of the major areas of Charter litigation. In quantitative terms, about two-thirds of Charter cases concern criminal law and the Court has been most likely to strike down state practices that violate the Charter in the area of criminal law than in any other area. ${ }^{6}$ While legislatures have the right to use the notwithstanding clause to override the Court's decisions on Charter issues, this weapon is rarely used. ${ }^{7}$ In the area of criminal law, the Court rules very directly on the behaviour of state actors such as the police and may directly terminate the prosecution of an accused citizen, order their release, and exclude evidence, if the Court rules that it has been obtained in a way that violates the rights guaranteed in the Charter. Therefore, in the area of criminal law, the Court has more power to directly implement its decisions through its impact on an ongoing prosecution than might be true in other areas. ${ }^{8}$

Using these strong levers, the Charter has reshaped specific areas of criminal law. Under the Charter, people cannot be detained unreasonably, held without habeas corpus, or denied the right to counsel. Court rulings have set limits on police behaviour in stopping people without cause, on the 
exclusion of evidence in criminal trials, and on searches. In the area of police investigations, court rulings have set limits on the detention and questioning of suspects. The Charter has been interpreted by the courts such that the police may only detain people on the basis of statutes such as the Highway Traffic Act or on the basis of common law' (and, in this case, the police must have a reasonable suspicion of recent or ongoing criminal behaviour ${ }^{10}$ ). Charter jurisprudence provides strong guarantees of the accused's right to be informed of the right to consult counsel without delay, the opportunity to consult counsel, ${ }^{11}$ and right to legal aid. ${ }^{12}$ Further, the courts have ruled that searches without a warrant are not reasonable, they have set limits on the wearing of a wire, videotaping, or entering a home to make an arrest, and they have ruled that certain evidence may be excluded if it was not collected in a reasonable way. In response, Parliament has refashioned criminal law to accord with the Charter by specifying the procedures under which warrants are issued and by specifying exceptions for extreme circumstances. ${ }^{13}$

The Charter has also shaped the criminal trial process in many areas, clarifying and setting limits on prosecutorial behaviour. A notable issue in this area is the rape shield.law in which those accused of rape may cite the complainant's past sexual history. While the court under the Charter has held that the accused should have the right to present a case claiming an honest understanding that consent had occurred, Parliament replied to this ruling by setting out legislation that balanced the right of the accused against the interests of victims of sexual assault in reporting crime, as well as in the right to privacy and other rights. ${ }^{14}$. Another area in which the Charter has set limits on criminal law is in the area of the fundamental rights of free expression and free assembly. In the area of pornography, for example, the Court ruled that free expression may be limited in response to a reasonable apprehension of the harm resulting from pornography or child pornography, although the Court allowed a defence of artistic, educational, or scientific merit. In addition, certain forms of hate speech may also be criminally prohibited as a reasonable limit on freedom of expression..$^{15}$

In sum, the Charter's clear enunciation of legal rights in sections 7-14 has not only provided some new protections for the accused, it has clarified previously existing protections. In response to Charter rulings on issues such as the exclusion of evidence or the conduct of searches without a warrant, the government has had to consider how to craft criminal law legislation that will deal with the limits set out by the courts. This has led to greater oversight of police and prosecutorial conduct.

In terms of the discursive effects of the Charter in the area of criminal law, the Charter has moved the conversation in the direction of the rights of the accused. This issue has become politicized as the post-Charter area of Canadian politics has seen the rise of populist right-wing politics through the Reform Party, the Canadian Alliance and the re-founded Conservative 
Party of Canada. The right-wing parties have attacked the Charter and the courts for upholding the rights of criminals at the expense of the rights of the accused. ${ }^{16}$ Taking a page from American debates on "law and order" (debates that arose in a very different context), ${ }^{17}$ right-wing populists have argued that the courts have moved the criminal law too far in the direction of the rights of criminals. At the same time, the women's movement is also deeply concerned with the shifts in criminal law in the direction of the rights of the accused and victims' rights groups have also called attention to their view that the system pays too much attention to the rights of criminals at the expense of the rights of the accused.

In his work on the impact of the Charter on criminal law, James Kelly argues that judicial activism in the area of legal rights and criminal law demonstrates that the courts have been farmore willing to limit the power of the police as unelected officials than to strike at the decisions of elected officials such as the cabinet or Parliament. Indeed, the courts are more deferential to the wishes of governments when money is involved, as cases such as pay equity and health spending show. Kelly argues that the framers of the Charter intended to limit police powers and to inject an element of American-style due process into police practices. Yet, Kelly argues, the framers of the Charter did not intend to take Canada to the extreme of U.S. due process at the expense of victims' rights. Rather, the intention was to create the constitutional context for a balanced approach to criminal law. ${ }^{18}$

In the area of lesbian and gay rights and same-sex relationship recognition, there can be little doubt that the entrenchment of the Charter had a powerful effect on the evolution of public policy, both instrumentally and discursively. In instrumental terms, the courts using the Charter have pushed the policy debate in the direction of full human rights protections for lesbians and gay men and in the direction of full recognition of the rights and obligations of civil legal marriage for same-sex couples. While the impact of the Charter on criminal law is found most particularly in sections 7-14 of the Charter that outline the legal rights of Canadians, the evolution of public policy in the area of lesbian and gay human rights is located in section 15 of the Charter, which protects equality rights on a range of enumerated grounds. The purpose of section 15 was to strengthen human rights protection in Canadian constitutional law, a goal that had long been articulated by many diverse groups in Canadian society and that, at the time of the debate on the Charter's entrenchment, was very strongly expressed by the women's movement, First Nations, and a broad range of ethnocultural communities. During debates on the proposed Charter in the parliamentary committee in the winter of 1980-81, Svend Robinson, NDP MP, asked then Justice Minister Jean Chrétien if the wording of enumerated grounds in the Charter might be extended to include sexual orientation as a prohibited ground of discrimination. In the exchange between Chrétien and Robinson, it was clear that, by leaving the list of enumerated grounds in section 15 open-ended, the authors of the Charter intended to permit the 
courts to "read in" analogous grounds of discrimination. When pressed on the question of including sexual orientation in the proposed Charter, Chrétien commented that it would be up to the courts to decide to read in sexual orientation as an analogous ground of discrimination under section $15 .{ }^{19}$

In the early years of Charter litigation under section 15 , it was not clear how the section would be applied to cases of sexual orientation discrimination. While Quebec had included sexual orientation in its human rights legislation in 1977, the idea that sexual orientation discrimination should be prohibited gained currency through debates over the Charter as influential human rights actors such as the Canadian and Ontario human rights commissions came out in favour of the amendment of provincial and federal human rights legislation to prohibit such discrimination. ${ }^{20}$ In early Charter cases in the late eighties and early nineties such as Veysey, ${ }^{21}$ Haig \& $B i r c h,{ }^{22}$ and Mossop, ${ }^{23}$ courts ruled that the exclusion of sexual orientation from the Canadian Human Rights Act violated section 15, the equality rights guarantees of the Charter. As a result of these decisions, it was widely understood in the legal community that sexual orientation had been "read into" the Charter of Rights and into the Canadian Human Rights Act through court decisions, despite the lack of a formal federal legislative amendment to the Act and despite the lack of a ruling from the Supreme Court of Canada. The Canadian Human Rights Commission itself was a strong supporter of the inclusion of sexual orientation within its ambit and immediately recognized the implications of the Veysey and Haig \& Birch decisions by accepting over two hundred complaints based on sexual orientation after 1992.24

In 1995, the Supreme Court ruled in Egan, ${ }^{25}$ its first case on sexual orientation discrimination of the post-Charter era. In this case, the Court ruled that sexual orientation was analogous to the other grounds of discrimination enumerated in section 15 and that, therefore, the power of the Charter would apply in this area of discrimination. However, the Court also ruled that the denial of spousal benefits to Egan and Nesbit was justifiable under the reasonable limits clause of section 1 of the Charter ${ }^{26}$ The possibility that the equality rights in section 15 of the Charter could be overridden by section 1's general limitation sparked the mobilization of a litigation coalition among groups including Egale, the main lesbian and gay rights group at the federal level, and other section 15 stakeholders, such as the Canadian Ethnocultural Council.

Changes in the personnel of the Supreme Court of Canada and mobilization by section 15 stakeholders seemed to bear fruit in the Vriend ${ }^{27}$ decision in 1998, which, along with the $M v H^{28}$ decision of 1999 , marked a turning point in the jurisprudence on lesbian and gay equality rights claims under the Charter. In Vriend, the Court ruled that Alberta had to permit gays and lesbians to have recourse to provincial human rights legislation and to 
hear the complaint of Delwin Vriend, a gay teacher who had been fired from his job. In the case of $M v . H$, the Court ruled that same-sex relationships were subject to the same spousal obligations as heterosexual common-law relationships upon breakup. In Vriend and $M v H$, the Court affirmed that sexual orientation was analogous to other grounds of discrimination in section 15 and moved away from the analysis of Egan by ruling that discrimination could not be justified under the reasonable limits clause of the Charter in section 1. In response to the $M v H$ decision, the federal government reviewed all federal statutes and passed blanket legislation in 2000 to include same-sex couples in all federal legislation. ${ }^{29}$

From this turning point, the door was open for the recognition of same-sex marriage, an issue that was litigated under the Charter from 1999 to 2004 , resulting in the passage of federal legislation legalizing same-sex marriage in June 2005. There can be little doubt that, without pressure from the courts, the Liberal government would not have moved so far so fast in the recognition of same-sex relationships. While the decisions of the courts could have been resisted by the Liberal government, once the courts had ruled that sexual orientation was included in section 15 and that discriminating against same-sex relationships was a form of sexual orientation discrimination, there was little doubt that the denial of same-sex marriage or the government's failure to amend its other statutes that deal with spousal status, would have led to a long and costly legal battle.

The discursive effects of the Charter in this policy area have been substantial. Both the Charter and the Supreme Court of Canada enjoy a high level of legitimacy among Canadians. ${ }^{30}$ Discrimination against lesbians and gay individuals and against same-sex relationships has been constructed and defined through the Charter as an issue of human rights. This can be contrasted with the political debate in the U.S. where the issue of same-sex marriage is routinely described as a "hot button" or an issue of morality. Although about $50 \%$ of Canadians opposed same-sex marriage in public opinion polls taken over the period from 2002-2007, the opponents of same-sex marriage have lost the discursive battle in framing this policy issue. ${ }^{31}$ The most recent public opinion research conducted over the $1990 \mathrm{~s}$ and 2000s shows that legal change has framed the issue in this policy area and has legitimated the recognition of same-sex relationships in the eyes of Canadians. ${ }^{32}$ The discursive effects of the Charter in this area have been strengthened by the timing of the litigation in this area, which coincided with the George W. Bush era in American politics, which has only distanced Canadians from the American-style morality politics. Because of the Charter's strong identification with English Canadian nationalism, the protection of lesbians and gays from discrimination, and the issue of same-sex marriage have become defined as points of national pride in English-speaking Canada, a discursive result that is further reinforced by the fact that, since the secularization of the Quiet Revolution, Quebecers have prided themselves on their openness on sexuality and their place as the 
first province to have implemented sexual orientation discrimination protections. ${ }^{33}$

Therefore, in these ways, the impact of the Charter in this policy area has been significant. In instrumental terms, the Charter is a powerful weapon that, through the process of litigation and legislative response to court decisions, has produced a clear-cut policy in which discrimination against lesbians and gays and against same-sex relationships is constitutionally prohibited. It is difficult to see how this policy result could have been achieved as cleanly and as quickly without the Charter. On the discursive side, the Charter has strengthened and broadened the definition of human rights in this sector, creating obstacles for same-sex marriage opponents. These two areas of policy - criminal law and lesbian and gay rightsprovide examples of the ways in which the Charter shapes policy outcomes through instrumental and discursive effects.

\section{The Effect of the Charter on Political Institutions}

The entrenchment of the Charter is usually presented as empowering courts relative to other political institutions. Right-wing Charter critics, especially those from the Reform/Alliance side of the revamped Conservative Party of Canada, argue that the courts have become too strong and that, with the Charter, courts have dictated to legislatures, enabling minority groups to circumvent the will of the democratic majority. Right-wing Charter critics argue that, by protecting minority groups, the Court oversteps its limits. This view of the Charter's effects may make good populist politics for right-wing politicians but it is not an accurate view of the effect of the Charter on Canadian political institutions. ${ }^{34}$ Judicial review using a constitutionally entrenched bill of rights is an institutional innovation that was designed in part with the goal of ensuring that minorities were not swamped by majorities in a democratic political system. Therefore, it is not useful to frame a normative debate solely with reference to the courts' alleged role in protecting so-called "special interests" at the expense of the role of Parliament. In fact, recent scholarship suggests that the role of the courts in the wake of the Charter has been much more complex way than what has been suggested in debates over judicial activism. In this section, consideration is given the impact of the Charter and of the growth of human-rights consciousness on other political institutions including Parliament, the executive, and the functioning of federalism.

Debates on judicial dialogue have opened up a discussion on the role of legislatures in policy-making on Charter issues. The advocates of judicial dialogue argue that Parliament plays a key role in responding to court decisions as well as in developing policies in light of the Charter and in light of the courts' likely reactions. ${ }^{35}$ In many cases, the courts explicitly leave certain policy issues to Parliament. In fiscal matters, for example, the Court has been increasingly deferential to Parliament. An excellent example is 
provided by the question of pay equity. In the $N A P E^{36}$ case, the Court ruled on a clear-cut case of sex discrimination in which women were paid less than men. The Court recognized that there was a section 15 violation of women's right to equal treatment under the law; however, the Court deferred to Parliament by stating that the Court could not make rulings in which there were substantial public expenditures at issue. ${ }^{37}$ Similarly, in the Auton ${ }^{38}$ case concerning access to medical treatment for children diagnosed with autism, the Court recognized that there were substantial fiscal issues in play for governments and did not require that the government provide expensive medical services. ${ }^{39}$ Therefore, courts often directly invite a dialogue through the nature of the decision they make in a Charter case or in the type of remedy they require. Because Parliament responds to the courts and clearly plays a role in the development of policy on Charter issues, advocates of "judicial dialogue" have argued that judicial activists are wrong to point to the dominant role of courts versus legislatures in the Charter era. ${ }^{40}$

As Janet Hiebert's work has shown, Parliament has a key role to play in debating and considering its legislative response on rights issues. For example, the area of criminal law, Parliament has debated the Court's rulings on questions such as the exclusion of evidence or the conditions under which warrants may be issued and has developed legislative responses that respond to the limits set by the courts. While critics of judicial activism see Parliament as acting as the headwaiter of the courts in these circumstances, a detailed consideration of the ways in which Parliament has responded on particular policy issues, shows that the courts rarely tell Parliament exactly what to do. Rather, Charter decisions set out the limits of state action and, in some cases, enjoin action from the state. However, there is almost always scope for interpretation of the Court's meaning in the legislative response or a choice of legislative means and instruments through which Parliament may respond. As Hiebert argues, legislatures and courts provide different answers to the fundamental rights' issues that are posed by the Charter. Hiebert's relational approach suggests that both courts and legislatures have a role to play in assessing the ways in which state actions live up to the precepts of fundamental rights laid out in the Charter. ${ }^{41}$

Therefore, rather than casting the impact of the Charter in terms of "judicial activism" versus "judicial dialogue," it is probably more accurate and more useful to see Parliament's response to the courts on Charter issues as evidence of the way in which the Charter has permeated Canadian political institutions in various ways. ${ }^{42}$ The Charter has certainly empowered Canadian courts, especially in specific areas such as criminal law and certain areas of human rights; as we have seen, this was in part the intent of the Charter's authors and it was a legal and constitutional framework that was strongly supported by legal and political elites at the time of the Charter's enactment. However, the Charter has also influenced 
other political institutions. Beyond the role of courts and legislatures, as highlighted in the "dialogue" approach and debates over judicial activism, the Charter has also shaped the executive, the bureaucracy, and the operation of Canadian federalism.

There can be little doubt that the Charter shapes the operation of the executive and the way in which policy is developed through the bureaucracy and the process of executive decision making by prime minister and Cabinet. Kelly's work shows the way in which the bureaucracy Charter-proofs laws as legislation is written and the pivotal policy role that is now played by the Department of Justice at the federal level in vetting legislation. The impact of the Charter on the policy process is much more profound than a simple assessment of the cases in which the courts strike down an existing government practice, procedure, regulation, or legislation based on Charter grounds. Rather, Kelly's work suggests that the Charter is at work behind the scenes at the stage of the crafting of legislation. ${ }^{43}$ The Charter has altered the policy process by encouraging the definition of policy problems in terms of rights and has provided a strategic instrument for the reinforcement of this definition. Although many public policy issues in Canada were defined through rights claims prior to the Charter, there is no doubt that the entrenchment of a constitutional bill of rights has institutionalized the practice of evaluating policy in terms of Charter rights.

The Charter poses particular limits for politicians. While dialogue theory focuses on the role of Parliament and seeks to expand the oversight role of Parliament in the development of the policy response to Charter rulings, under most political circumstances, the role of the legislature in the Westminster system is limited with respect to policy-making. This is especially so given the strictures of the first-past-the-post electoral system that increase the incentives for party discipline. Canada has a high level of legislative cohesion compared to other democracies, which reduces the policy effectiveness of parliamentary deliberation and debate. While deliberation through the legislative committee system can provide a forum for broad-ranging debates on policy areas and, specifically, for the inclusion of civil society groups and other actors (including expert individuals) to deliberate with legislators on policy issues, decisions are made by the party leadership as a government. In the circumstances of majority government, the governing party controls the committees and may decide to accept or reject their advice. Even in circumstances of minority government, the process of negotiating and bargaining occurs among party leaders and elites and strengthens the hand of these actors in the policy process.

Political scientists have noted for many years the rise of American-style presidential government among parliamentary democracies and have debated the extent to which prime ministers have become increasingly presidential and powerful. This tendency has always been pronounced in 
Canada where the legislative process is dominated by the executive. Just as party discipline and the cohesion of the parties in the legislature is much greater in Canada than in other similar political systems, so too the dominance of the executive, especially in periods of majority government, is unrivalled among other Westminster systems. ${ }^{44}$ This tendency has been exacerbated and reinforced by the centralization of power in the hands of central agencies such as the Privy Council Office and the Prime Minister's Office (PMO), a centralization that began in the Trudeau era when the powers of central agencies were increased in order to counterbalance the power of the traditional bureaucracy. ${ }^{45}$ In this centralization of power, the Department of Justice plays a key role in the Charter era because of its Charter-proofing role that crosscuts policy jurisdictions. However, the centralization of power in the hands of the prime minister has also led to the strengthening of the political and partisan advisors, institutionally located in the PMO but also scattered among the offices of cabinet ministers. The accelerating mediatization of politics brought about the concentration of media ownership and the shift to even more globalized communications, means that party financing focuses on securing access to media. The rise of a new class of pollsters and professional lobbyists has displaced the traditional bureaucratic advice from the expert public servant. These trends have been described by Donald Savoie as leading to an unprecedented concentration of power in the hands of the prime minister. ${ }^{46}$ This centralization of power means that the concept of "judicial dialogue" must be tempered with the understanding that the discussion of the "legislative response" to Charter decision is often not a response that comes from the legislature in any meaningful sense. Rather, the "parliamentary" or "legislative" response comes from the executive, the prime minister and the cabinet, often acting on the advice of the expert lawyers in the Department of Justice as the dominant central decision maker in the public service on Charter issues, but also on the advice of pollsters and partisan political advisors who are concerned about the electoral fortunes of the prime minister and the governing party. ${ }^{47}$

Of course, there is nothing new about the idea that policy decisions are made in response to the dynamics of electoral competition and we could argue that, indeed, such democratic responsiveness is how the system is supposed to work. Savoie's point is that there are fewer checks and balances in the system than there once were because of the decline of the traditional advice of the public servant. ${ }^{48}$ In this sense, one could argue that the Charter plays a democratizing role in the Canadian political system by forcing politicians back to the advice of the expert public servant, whose role is to provide non-partisan advice, even if, in practice, the expert public servant is a lawyer whose advice will be bound by the limits of legal thinking and even if, in practice, the expert public servant's role as expert cannot always be easily be distinguished from a "political" role. Yet, the public servant who is paid by the state to serve all political parties over the course of her career is 
in a different situation than a partisan political advisor who will be out of office if the prime minister loses an election. The Charter forces the legal expert front and centre in the policy process and this provides some check on the rampant growth of the for-profit political class of pollsters, lobbyists, and partisans.

Aside from the Charter's effects on the balance of "expert"vs. "partisan" advice received by the prime minister and Cabinet and the weight of this advice in decision making at the top level of the executive, the Charter has also affected the dynamics of electoral competition. Charter decisions have often played a role in political campaigns and, on occasion, have provided wedge issues for the rise of the partisan right. Much of the scholarly campaign by critics of judicial activism in both Canada and the U.S. has come from those associated with the partisan political right. ${ }^{49}$ In the U.S., these concerns have crystallized since the $1960 \mathrm{~s}$ in an association between judicial activism and a range of social and political hot buttons such as abortion, gun control, the death penalty, and "gay rights." In Canada, the partisan right has pushed to politicize the Court's role in imitation of their more successful American counterparts, arguing that the Court has given too much power to specific groups and overstepped the bounds of law into the realm of policy and politics. As member of Parliament for the Canadian Alliance, prior to his role as Justice Minister in the Harper minority government, Vic Toews well represented this view when he stated that "[u]nder the assumed authority of the Canadian Charter of Rights and Freedoms the courts have moved beyond their traditional role as arbiters of legal disputes and into the realm of policy making. Indeed, they have become politicians." 50 Toews went on to say that "[a]n unaccountable and unelected judiciary has simply and erroneously appropriated the jurisdiction to legislate by judicial fiat matters of social policy." As Toews outlined his views to the House of Commons, the three groups that had benefited most from the overweening arrogance of the courts were federal prisoners, "child sexual predators," and same-sex couples. ${ }^{51}$

If right-wing politicians wish to check the Court's power, the most effective vehicle for this would be the use of the notwithstanding clause, section 33 of the Charter, whose precise purpose is to allow legislatures (federal and provincial) to pass legislation notwithstanding sections 2 and $7-15$ of the Charter. For example, by using the notwithstanding clause, the Harper government could repeal the 2005 same-sex marriage legislation and pass federal legislation to ban same-sex marriage in Canada, declaring this legislation to operate notwithstanding the rights of same-sex couples as recognized and protected by the courts in the equality rights (section 15) of the Charter. The impact of the Charter on electoral competition has not been extensively canvassed in the literature; yet, considering the role of the Charter in providing electoral cannon fodder for party competition 
provides another example of the way in which the Charter permeates the Canadian political system.

Finally, the Charter has had important effects on that most important Canadian political institution-federalism. The political purpose of the Charter, as Peter Russell pointed out at its inception, was, in part, to deflect regional and provincial identities in favour of a stronger concept of Canadian citizenship and a stronger sense of attachment between the central government and the individual. ${ }^{52}$ The Charter has set out new limits on Canadian federalism by empowering the individual and collective rights of citizens against governments, as Alan Cairns has argued. ${ }^{53}$ Provincial governments cannot assert their individual policy preferences in provincial jurisdiction if their preferences violate the rights outlined in the Charter. Certainly, the power of provinces has been limited by the Charter. The Charter has had a particularly important direct effect in the area of language policy, as it was intended by its framers. Provincial language policies are subject to the jurisdiction of the Charter. The Trudeau vision of Canadian federalism, in which individuals would enjoy the right of access to federal government services in French or English and the right to educate their children in English or French across Canada, is enshrined in section 23 of the Charter, which immediately collided with Quebec's language law, the PQ's Bill 101. It is important to note, however, that the Charter has served as a lever-however imperfect-to force recalcitrant governments in other provinces such as Manitoba to provide better access to schools and services for their francophone minorities. ${ }^{54}$ As the case of Vriend shows, the Charter has also brought provinces into line with regard to fundamental rights and has created a common template for such rights in particular sectors, especially in the area of lesbian and gay rights. Because lesbian and gay rights policies have changed so radically since the coming into force of the equality rights section of the charter in 1985, they provide a strong example of a case in which provinces have been forced to adhere to a common human rights standard as a result of Court decisions.

At the same time, this view of the Charter's role must be balanced by considering the larger context of the evolution of federalism over the last thirty years and reduced role of the federal government compared to provincial governments. For example, the forces of globalization as well as Canada's participation in the neo-liberal trade regimes of the World Trade Organization and the North American Free Trade Agreement have limited both federal and provincial powers. ${ }^{55}$ Therefore, it is difficult to argue that the Charter has had clear-cut effects on centralizing or decentralizing Canadian federalism. Rather, the Charter, reinforces human rights considerations in the operation of Canadian federalism and creates new limits on both federal and provincial powers. 


\section{The Effect of the Charter on Political Mobilization}

Most discussions of the Charter's effects focus on its concrete impact in shaping public policy. Indeed, it is often assumed that court decisions have direct effects on public policy and that, once the courts rule, governments are obligated to immediately take some concrete action to conform to the decision. Yet, in some cases, court decisions are not implemented and policies are not carried out in a clear-cut fashion. An example can be found in the case of language rights in Manitoba and other anglophone provinces. While the Charter has resulted in a series of court decisions in favour of the rights of minority francophone groups through English-speaking Canada, it is also true that these decisions have proven to be problematic in implementation, forcing francophone minority groups to return to court again and again in order to ensure implementation of court decisions. While it is true that the Charter has strengthened the hand of the courts and that, as I have argued here, that it has permeated the operation of Canadian political institutions, we can also consider the Charter's effects beyond the realm of state institutions, the courts, and the evolution of jurisprudence on human rights by considering more broadly the effect of the Charter on political mobilization. By political mobilization, I mean simply the organization, strategies, and ideologies of civil society groups, especially those that seek to influence the state. Law on paper means nothing unless it is supported by social norms and practices. Exploring the impact of the Charter's human rights consciousness on societal actors is thus part and parcel of exploring the effectiveness and reality of legal change. In this section, I will briefly consider the effect of the Charter on the constitutional debate about human rights and the effect of the Charter on social movements and partisan political party conflict.

During the debates on the Charter's entrenchment and in the period following, a number of observers noted that the advent of the Charter had empowered citizens and citizen groups in constitutional debate and that this process of citizen empowerment could be contrasted with the traditional intergovernmentalism. ${ }^{56}$ Federalism was the business of governments. By definition, intergovernmentalism referred to the dynamic process of government-to-government negotiation, especially in the postwar era of executive federalism in which the growing Canadian welfare state was managed through federal-provincial transfers and other forms of intergovernmental coordination. As Richard Simeon pointed out in his well-known study of the negotiation of the Canada Pension Plan, the process of intergovernmental negotiation tended to be closed to outside group influence. ${ }^{57}$ This meant that considerations such as the human rights of citizens or groups of citizens could not easily find entry into debates dominated by considerations of federalism, and that human rights issues were often redefined in terms of federal and provincial powers ${ }^{58}$ Even when courts were faced with human rights issues in the pre-Charter era, the Canadian constitution provided more levers for making decisions on 
federalism grounds than on human rights grounds (with the exception of section 93's guarantees for denominational schools). The original "problem" that sparked the constitutional debates was the problem of constitutional amendment and debates on various formulas for amendment revolved around the rights of governments in constitutional amendment rather than the rights of citizens. As Alan Cairns pointed out, the constitutional rounds following the Charter's entrenchment-the two rounds that attempted to bring Quebec into the Constitution, the Meech Lake Accord round (1987-1990) and the Charlottetown Accord round (1992) - the Constitution of governments came into conflict with the Constitution of citizens. As Cairns argued, the Charter created a new political dynamic in which citizens (as individuals and as groups) had received constitutional recognition of their rights and, therefore, had become constitutional actors with powers and resources of their own-powers and resources that were provided and legitimated by the Charter. ${ }^{59}$

This conflict between the rights of governments and the rights of citizens played out through the Meech Lake and Charlottetown rounds. The constitutional changes that were intended to give more power to the government of Quebec as the national representative of Québécois or that were intended to give more powers to all the provinces as a means of propitiating Quebec nationalism and Western regionalism clashed with the rights guarantees of the Charter. The Charter provided clear-cut constitutional protection of fundamental rights for many groups in Canadian society that had never had such protections before including women, ethnocultural minorities, Aboriginal peoples and others. The prospect of the coming into force of section 15 (equality rights) of the Charter in 1985, had already sparked major political debate and consultation through the parliamentary committee hearing and stakeholder groups were keen to ensure that the new Charter would not be a dead letter like the Canadian Bill of Rights, but that it would be a generously interpreted living document that would provide a higher standard of human rights protections for Canadians. Therefore, when there appeared to be a conflict between the Charter on the one hand and the provisions of the Meech Lake and Charlottetown Accords on the other hand, the constitutional debates pitted the human rights ideas of the Charter against the national vision of both Quebecers and Aboriginal peoples and against the rights of governments, especially provincial governments, which sought to expand provincial jurisdiction and rights in the constitutional debates.

The clash between the Charter-based vision of human rights and the national vision of constitutional rights came to a head in December 1988, when the government of Quebec acted to maintain language laws ensuring French predominance on public signage. ${ }^{60}$ Quebec exempted itself from language laws of the Charter in order to defend its national vision of the 
right of the provincial government to control language policy and the right of a nation to protect its cultural identity. This clash between the human rights of the Charter and the collective national rights of Quebecers galvanized opposition to the Meech Lake Accord and set the stage for the conflicts of the subsequent constitutional round. Through the Charlottetown Accord, Charter stakeholders, such as the women's movement in English-speaking Canada, argued against provincial decentralization and against constitutionally entrenched legal guarantees of Quebec's distinctiveness that might undermine the recognition of women's rights. A similar dynamic occurred in the debate on the application of the Charter in Aboriginal communities. Therefore, the Charter reinforced the political position of human rights stakeholders. As Cairns argues, by providing constitutional recognition to Charter stakeholders, the constitutional change of 1982 provided an opening for a much broader range of citizen participation in constitutional debates. Much of that opening was seized by the Charter stakeholders. Although the constitutional debates of 1987-1992 resulted in an impasse, they produced a rich debate among political actors on the relationship between human rights, nationalism, and constitutionalism-one that fuelled Canada's unique contributions to political theorizing about minority and human rights. ${ }^{61}$ For the first time, groups such as First Nations and the women's movement, which had historically been marginalized in Canadian constitution making, were included and officially recognized as having the right to participate in the constitutional conversation. This change in the process of political mobilization can be attributed at least in part to the impact of the Charter.

The Charter has also had important effects for the ways in which groups mobilize in the political process. First, the Charter also encourages a policy discourse in which problems are cast in terms of rights and many analysts see this process as one that reinforces neo-liberalism. For example, Ran Hirschl argues that judicial empowerment has led to increased power for elites, especially economic elites, to dominate the democratic process at the expense of other interests. ${ }^{62}$ The Critical Legal Studies School of legal analysis emphasizes that the legal system favours certain types of claims and produces and reinforces the existing power system. Judy Fudge's analysis of Charter decisions shows that claims for recognition are much more likely to succeed in Charter jurisprudence than claims with fiscal implications. Thus, claims for same-sex relationship recognition succeed because, mainly, these are claims for recognition that do not cost the state; in contrast, the pay equity claims of women are not recognized by the court even though they entail a straightforward claim of sex discrimination. ${ }^{63}$

The perils of Charter-based human rights discourse are also exemplified by the ongoing failure of the government to remedy problems that might seem to fall clearly within the ambit of human rights. Thus, legal and 
Charter-based strategies are not always the best choice for collective actors. For example, violence against women has not been remedied, despite the legal guarantees of equality in the Charter. In section 15, the Charter states that discrimination on the grounds of sex (and other grounds) is prohibited and, in section 28, the Charter states that all of the rights in it are guaranteed equally to male and female persons. Yet, it is very challenging to litigate with the Charter in defence of the right of women to be free of male violence. As discussed, those accused of assault are protected by the Charter's guarantees of due process, which were intended by the framers of the Charter to protect the accused against police power and to ensure that the police were accountable for their conduct. ${ }^{64}$ The problem of violence against women is framed as a policy issue that entails a clash of rights, between the accused and the victims of violence. Nonetheless, as a public policy issue, violence against women might be defined as a question of social, political, and economic justice. As the Canadian Association of Sexual Assault Centres points out, violence against women must also be seen against the backdrop of the declining role of the welfare state, the erosion of the social safety net, the decline in social assistance rates, and the overall increase in economic inequality in Canadian society. Economic inequality leaves women with fewer options and means that collective resources, such as battered women's shelters and rape crisis centres, lead underfunded and precarious lives. ${ }^{65}$ The Charter does not encourage the framing of the issue in terms of economic and social inequality and the scaled-based welfare state because these socio-economic issues are not included in its mandate.

Second, the Charter also affects the ways in which groups mobilize in the policy process by privileging litigation strategies over other forms of political mobilization. Early on in the Charter's life, Michael Mandel argued that the entrenchment of the Charter would lead to the legalization of politics in Canada by defusing grassroots political activism in favour of litigation. Mandel's argument focussed on the case of Operation Dismantle that attempted to stop nuclear testing in Canada. He argued that the legal opening provided by the Charter encouraged the peace movement to litigate and that this process undermined the movement's ability to mount grassroots mobilization campaigns. ${ }^{66}$ The Charter's structuring effect on political organizing can also be seen in the politics of the women's movement and the politics of the lesbian and gay movement. Both these movements are deeply diverse with a large number of grassroots organizations at the urban and local levels. Yet, at the pan-Canadian level, each movement has only one organization and, in both cases, it is an organization that focuses on Charter litigation. Since the demise of the National Action Committee on the Status of Women (NAC) as the pan-Canadian voice of the women's movement, the Women's Legal Education and Action Fund (LEAF), a Charter litigation fund, is the most high profile voice for the national women's movement. In the case of 
lesbian and gay rights, Egale, the main national voice in this sector, has devoted considerable energy to litigation under the Charter. In these cases, then, the Charter encourages social movement organizations to focus on the litigation of human rights claims rather than pursuing politics by other means.

Finally, in considering the effect of the Charter on political mobilization, it is important to think about the way in which human rights play out in partisan political competition. The Charter has played an increasingly important role in partisan party competition over the course of the 1990s and 2000s. The Liberals have successfully exploited Charter issues for their own political gain by claiming the mantle of equality rights as the particular project of the Liberal Party. In the 2004 election, Paul Martin offered to eliminate the notwithstanding clause, a gesture that, however impracticable, symbolized the Liberal identification with the Charter. ${ }^{67}$ Countering the rise of the Reform Party, the Canadian Alliance and, since 2003, the revamped Conservative Party of Canada, the Liberals have used the Charter to point to the differences between their party and their increasingly right-wing political opponents. On economic and social policy issues, the Liberals have drifted steadily to the right since 1993. During their period of opposition to the Mulroney Conservatives, the party painted itself as a champion of progressive Canadians in opposition to NAFTA and in defence of the collectivist welfare state. Yet, as soon as the Liberals were elected under Jean Chrétien in 1993, they began their move to the right, starkly epitomized by Paul Martin's 1995 budget from which intergovernmental transfers for social policy have never recovered. Martin's slash-and-burn return to balanced budgets and the Chrétien government's embrace of NAFTA were consistent with the party's long-term habit of running from the left and governing from the right. ${ }^{68}$

However, the danger in this strategy was the vulnerability of the party to the charge that it had drifted so far to the right that it has become indistinguishable from the Conservatives. The disarray of the right as a result of the bust-up of the Mulroney electoral coalition and the rise of the five-party system with the Bloc and the Reform Party allowed the Liberals to rule unchallenged for a decade. However, throughout this period, the Liberals used social liberalism to distinguish themselves from their opponents on the right and this strategy crystallized around the issue of same-sex marriage. How a political party and government that could barely bring itself to officially amend the Canadian Human Rights Act to include sexual orientation as a ground of discrimination in 1996 became a political party that passed legislation to legalize same-sex civil marriage in 2005 is a story that hinges on the political role of the Charter in Canadian politics. After the persistent pattern of court rulings in favour of lesbian and gay rights under the Charter from 1998 on, the Liberals reluctantly embraced this cause, turning a set of policies that were personally uncomfortable for 
Prime Ministers Chrétien and Martin and policies that were not supported by the entire Liberal caucus, into a cause with which the Liberal Party is now identified. The party exploits the social conservatism of the right to vaunt its own role as author and defender of the Charter on issues such as same-sex marriage, drawing a link between the Liberal Party's defence for the rights of gays and lesbians and its defence of the rights of ethnocultural minorities, its history as the political party that opened up Canadian immigration on a non-racial basis, and its role as defender of "Canadian values"-values equated with the Charter. In this way, the Charter has become identified with nationalist discourse in English-speaking Canada and has become a marker of Canada's difference from the U.S.

\section{Conclusion}

Recent historical scholarship has reminded us of the roots of human rights struggles in the period prior to the Charter. The Charter was, in part, the product of a long-running debate in Canadian politics, dating back to the negotiation of the Confederation agreement and before in which British North Americans and, later, Canadians, thought about how to develop parliamentary political institutions and how to recognize legal and political rights based on differences such as religion. The post-World War I period saw the beginnings of political activism on issues of civil liberties and racial discrimination, an activism that culminated in the Diefenbaker Bill of Rights. The failings of this initial foray, in part, provided the background and political support for the Trudeau government's initiatives in the constitutional debates of the 1970 s and early 1980 s, leading to the Charter's entrenchment.

The effects of the Charter on public policy, political institutions, and political mobilization have occurred, in part, because of the broad social and political support for human rights in Canada, itself a product of activism, political struggle, and strategic litigation. The Charter has realized John Diefenbaker's goal in working for a statutory bill of rights, namely to force Parliament to consider and debate rights issues. While Diefenbaker was principally concerned with civil liberties and he envisioned this conversation about rights as occurring within the confines of Parliament, the effects of the constitutionally entrenched Charter have been much broader and deeper. Not only has the Charter shaped public policy outcomes in specific areas such as criminal law and lesbian and gay rights, it has also framed public debates and shaped the process by which legislation is developed and drafted. While the Charter has strengthened the hand of the judiciary relative to other political institutions, the discursive and instrumental effects of the Charter are also felt in other political institutions such as the executive and Parliament as well as the operation of federalism. Perhaps most importantly, the Charter has become an important factor in structuring political mobilization and debate, encouraging civil society organizations to stake their political claims in 
terms of Charter rights (for better or ill) and contributing to the partisan competition between political parties in federal politics. From the perspective of the twenty-five years since its entrenchment, the Charter has permeated Canadian political debates, political institutions, and political mobilization and has become an important fixture in Canadian political life.

\section{Notes}

1. This research was supported by the Social Sciences and Humanities Research Council of Canada and this support is gratefully acknowledged. Carolyne Kerr and Jacqueline Krikorian provided useful comments on this paper. Sole responsibility for errors and omissions lies with the author.

2. Michael Ignatieff, The Rights Revolution (Toronto: Anansi, 2000).

3. Ran Hirschl, Towards Juristocracy: The Origins and Consequences of the New Constitutionalism (Cambridge: Harvard University Press, 2004).

4. This article uses the term "human rights" to encompass both civil rights and equality rights. On the distinction between civil rights and equality rights in the history of Canadian rights activism, see Ross Lambertson, Repression and Resistance: Canadian Human Rights Activists 1930-1960 (Toronto: University of Toronto Press, 2005).

5. Matt James, Misrecognized Materialists: Social Movements in Canadian Constitutional Politics (Vancouver: University of British Columbia Press, 2006); Lambertson, 2005; Christopher MacLennan, Toward the Charter: Canadians and the Demand for a National Bill of Rights, 1929-1960 (Montreal and Kingston: McGill-Queen's University Press, 2003); James W. St. G. Walker, "Race," Rights and Law in the Supreme Court of Canada: Historical Case Studies (Waterloo: Wilfred Laurier University Press, 1997): 122-181; Carmela Patrias and Ruth A. Frager, "This is our country, these are our rights'; Minorities and the Origins of Ontario's Human Rights Campaigns," Canadian Historical Review 82: 1 (March 2001): 1-35; Stephanie D. Bangarth, "We are not asking you to open wide the gates for Chinese immigration': The Committee for the Repeal of the Chinese Immigration Act and Early Human Rights Activism in Canada," Canadian Historical Review 84: 3 (September 2003): 395-422; and "Shirley Tillotson, "Human Rights Law as Prism: Women's Organizations, Unions, and Ontario's Female Employees Fair Remuneration Act, 1951," Canadian Historical Review 72: 4 (1991): 532-557.

6. James B. Kelly, Governing with the Charter: Legislative and Judicial Activism and Framers' Intent (Vancouver: University of British Columbia Press, 2005): 107.

7. Tsvi Kahana, "Understanding the Notwithstanding Mechanism," University of Toronto Law Journal 52: 2 (Spring 2002): 221-274.

8. On problems with the implementation of legal decisions, see Gerald $\mathbf{R}$. Rosenberg, The Hollow Hope: Can Courts Bring About Social Change (Chicago: University of Chicago Press, 1993): 172-184.

9. R. v. Simpson [1993] 79 C.C.C. (3d) 488 (OCA).

10. R. v. Mann [2004] 3 S.C.R. 59.

11. R. v. Manninen [1987] 1 S.C.R. 1233.

12. R. v. Brydges [1990] I S.C.R.

13. Kent Roach, Criminal Law $3^{\text {rd }}$ ed. (Toronto: Irwin Law, 2004): 32-34.

14. Roach: $40-41$. 
15. Roach: 54-55.

16. For example, Stephen Harper, Address by the Prime Minister on the Government's commitment to get tough on crimes involving weapons, gangs and drugs (April 19, 2006) online at: http://pm.gc.ca/eng/media.asp?category=2\&id= 1127.

17. Katherine Beckett, Making Crime Pay: Law and Order in Contemporary American Politics (New York: Oxford University Press, 1997).

18. Kelly: $108 \mathrm{ff}$.

19. Miriam Smith, Lesbian and Gay Rights in Canada: Social Movements and Equality-Seeking, 1971-1995 (Toronto: University of Toronto Press): 72-73.

20. Canada, Special Joint Committee on the Constitution of Canada, Minutes of Proceedings and Evidence, 1980-81: 5: 24ff. See also David Rayside, "Gay Rights and Family Values: The Passage of Bill 7 in Ontario." Studies in Political Economy 26 (Summer 1988): 109-147.

21. Correctional Services of Canada v. Veysey (1990), 109 N.R.

22. Haig \& Birch (1992), 9 O.R. (3d) 495, 94 D.L.R. (4th) 1, 16 C.H.R.R. D/226, 57 O.A.C. 272,10 C.R.R. (2d) 287.

23. Canada (A.G.) v. Mossop [1993] 1 S.C.R. 554.

24. Nitya Iyer, "Categorical denials: Equality rights and the shaping of social identity." Queen's Law Journal 19: 1 (Fall 1993): 179-207; Douglas Sanders, "Constructing Lesbian and Gay rights." Canadian Journal of Law and Society 9: 2 (Fall 1994): 350-379.

25. Egan \& Nesbitt v. Canada 124 D.L.R. (4th) 609 SCC.

26. For an overview of these early efforts, see Hiebert, 170-198.

27. Vriend v. Alberta [1998] I S. C. R. 493.

28. $M v . H[1999]$ S. C. J. No. 23.

29. Miriam Smith, "Recognizing Same-Sex Relationships: The Evolution of Recent Federal and Provincial Policies," Canadian Public Administration 45: 1 (Spring 2002): 1-23.

30. Joseph F. Fletcher and Paul Howe, "Supreme Court Cases and Court Support: The State of Canadian Public Opinion," Choices 6: 3 (May 2000). On public support for federal, provincial, and territorial human rights legislation, see also $\mathrm{R}$. Brian Howe and David Johnson, Restraining Equality: Human Rights Commissions in Canada (Toronto and Buffalo: University of Toronto Press, 2000): 150-168.

31. Patrick Fournier, André Blais, Joanna Everitt, Elisabeth Gidengil, and Neil Nevitte. "How the Liberals Lost Quebec." Globe and Mail (July 21, 2004): A15; Michael Adams, Fire and Ice: The United States, Canada, and the Myth of Converging Values. (Toronto: Penguin, 2004); Ipsos Reid. "Slim Majority (54\%) Support Same-Sex Marriage" www.ipsos-reid.com (June 13, 2003).

32. J. Scott Matthews, "The Political Foundations of Support for Same-Sex Marriage in Canada," Canadian Journal of Political Science 38: 4 (2005): 841-866.

33. On the relationship between sexuality and nationalism with specific attention to Canada and Quebec, see Carl F. Stychin, A Nation by Rights: National Cultures, Sexual Identity Politics, and the Discourse of Rights (Philadelphia: Temple University Press, 1998).

34. For overview of this debate, see Miriam Smith, "Ghosts of the JCPC: Group Politics and Charter Litigation in Canadian Political Science," Canadian Journal of Political Science 35: 1 (March 2002): 3-29.

35. Peter W. Hogg and Allison A. Bushnell, "The Charter Dialogue between Courts and Legislatures," Osgoode Hall Law Journal 1997: 75-124. 
36. Newfoundland Treasury Board v. Newfoundland and Labrador Association of Public and Private Employees (N.A.P.E.), [2004] 3 S.C.R. 381.

37. Sujit Choudhry and Claire Hunter, "Measuring Judicial Activism on the Supreme Court of Canada: A Comment on Newfoundland (Treasury Board) $v$. Newfoundland Association of Public Employees" McGill Law Journal 48: 3 (2003): 525-562.

38. Auton (Guardian ad litem of) v. British Columba (Attorney General), [2004] 3 S.C.R. 657.

39. On Auton, Fiona Sampson, "The Law Test for Discrimination and Gendered Disability Inequality," in Fay Faraday, Margaret Denike, and M. Kate Stephenson (eds.) Making Equality Rights Real: Securing Substantive Equality Under the Charter (Toronto: Irwin Law, 2006): 245-273. On Auton and NAPE, Melanie Randall, "Equality Rights and the Charter: Reconceptualizing State Accountability for Ending Domestic Violence," in Fay Faraday, Margaret Denike, and M. Kate Stephenson (eds.) Making Equality Rights Real: Securing Substantive Equality Under the Charter (Toronto: Irwin Law, 2006) pp. 275-317.

40. Hogg and Bushnell, 75-124.

41. Janet L. Hiebert, Charter Conflicts: What is Parliament's Role? (Montreal and Kingston: McGill-Queens University Press, 2002), 43-72.

42. Kelly, 107.

43. James B. Kelly, "Bureaucratic Activism and the Charter of Rights and Freedoms: The Department of Justice and its Entry into the Centre of Government," Canadian Public Administration 42: 4 (Winter 1999), 476-511.

44. For an excellent overview of the Canadian executive in comparative perspective, see Herman Bakvis and Stephen Wolinetz, "Canada: Executive Dominance and Presidentialization," in Thomas Poguntke and Paul Webb (eds.) The Presidentialization of Politics: A Comparative Study of Modern Democracies (Oxford: Oxford University Press, 2005), 199-220. Bakvis and Wolinetz disagree somewhat with Savoie over the extent to which presidentialization or prime ministerial dominance is new in Canadian politics, emphasizing the historical persistence of executive dominance.

45. For an overview of the functioning of the presidential-style prime-ministerial centred Cabinet, see Michael Howlett, Luc Bernier, Keith Brownsey, and Christopher Dunn, "Modern Canadian Governance: Political-Administrative Styles and Executive Organization in Canada in Michael Howlett, Luc Bernier, Keith Brownsey, and Christopher Dunn (eds.) Executive Styles in Canada: Cabinet Structures and Leadership Practices in Canadian Government (Toronto: University of Toronto Press, 2005), 3-13.

46. Donald J. Savoie, Governing from the Centre: The Concentration of Power in Canadian Politics (Toronto: University of Toronto Press, 1999); Donald J. Savoie, "The Rise of Court Government in Canada," Canadian Journal of Political Science 32: 4 (1999): 635-664. For a recent reconsideration, see Donald J. Savoie, "The Federal Government: Revisiting Court Government in Canada," in Michael Howlett, Luc Bernier, Keith Brownsey, and Christopher Dunn (eds.) Executive Styles in Canada: Cabinet Structures and Leadership Practices in Canadian Government (Toronto: University of Toronto Press, 2005): 17-43.

47. On government responses in Charter cases, see Matthew A. Hennigar, "Expanding the "Dialogue" Debate: Canadian Federal Government-Responses to Lower Court Charter Decisions," Canadian Journal of Political Science 37: 1 (March 2004): 3-21. 
48. Donald Savoie, Breaking the Bargain: Public Servants, Ministers and Parliament (Toronto: University of Toronto Press, 2003).

49. Marci McDonald, "The Man Behind Stephen Harper" Walrus, May 9, 2005 online at: http://www.walrusmagazine.com/article.pl?sid=05/05/09/21 19243 .

50. Hansard, 138: 98, $2^{\text {nd }}$ session of the $37^{\text {th }}$ Parliament (May 8, 2003).

51. Toews' exact motion was worded as follows: "That this House call upon the government to bring in measures to protect and reassert the will of Parliament against certain court decisions that: (a) threaten the traditional definition of marriage as decided by the House as, "the union of one man and one woman to the exclusion of all others"; (b) grant house arrest to child sexual predators and make it easier for child sexual predators to produce and possess child pornography; and (c) grant prisoners the right to vote." Hansard, 138: 98, $2^{\text {nd }}$ session of the $37^{\text {th }}$ Parliament (May 8, 2003).

52. Peter Russell, "The Political Purposes of the Canadian Charter of Rights and Freedoms," Canadian Bar Review 61 (1983): 30-54.

53. Alain Cairns, The Charter versus Federalism: Dilemmas of Constitutional Reform (Montreal and Kingston: McGill-Queen's University Press, 1992).

54. Maureen Covell, "Minority Language Policy in Canada and Europe: Does Federalism Make a Difference?" in Herman Bakvis and Grace Skogstad (eds.) Canadian Federalism: Performance, Effectiveness, and Legitimacy (Don Mills: Oxford University Press, 2002): 244-45. Nelson Wiseman argues that, as of 1992, the Charter made very little difference for Manitoba francophones. See "The Questionable Relevance of the Constitution in Advancing Minority Cultural Rights in Manitoba," Canadian Journal of Political Science 25: 4 (1992): 697-721

55. Stephen McBride, "Quiet Constitutionalism in Canada: The International Political Economy of Domestic Institutional Change," Canadian Journal of Political Science 36: 2 (2003): 251-273.

56. Peter Russell, Constitutional Odyssey: Can Canadians Become a Sovereign People? $3^{\text {rd }}$ ed. (Toronto: University of Toronto Press, 2004) and Cairns, The Charter versus Federalism.

57. Richard Simeon, Federal-Provincial Diplomacy: The Making of Recent Policy in Canada (with a new preface and postscript). (Toronto: University of Toronto Press, 2006).

58. On the dynamics of the citizens' constitution vs. the governments' constitution, see Cairns, The Charter and James, Misrecognized.

59. Cairns, The Charter.

60. Jennifer Smith, Federalism (Vancouver: University of British Columbia Press, 2004), 60-61.

61. Among many others, Will Kymlicka, Multicultural Citizenship: A Liberal Theory of Minority Rights (Oxford: Oxford University Press, 1995), Charles Taylor, "Multiculturalism and the Politics of Recognition," in Amy Gutman (ed.) Multiculturalism: Examining the Politics of Recognition (Princeton: Princeton University Press, 1992) and James Tully, Strange Multiplicity (Cambridge: Cambridge University Press, 1995).

62. Hirschl, Towards Juristocracy.

63. Judy Fudge, "The Canadian Charter of Rights: Recognition, Redistribution and the Imperialism of the Courts," in Tom Campbell, K.D. Ewing, and Adam Tomkins (eds.) Sceptical Essays on Human Rights (Oxford: Oxford University Press, 2001): 335-358. 
64. James B. Kelly, Governing with the Charter: Legislative and Judicial Activism and Framers 'Intent (Vancouver: University of British Columbia Press, 2005), $108 \mathrm{ff}$.

65. Lee Lakeman, "Canada's Promises to Keep: The Charter and Violence Against Women" 2003 online at http://www.casac.ca/english/canadas.promises.to.keep.htm

66. Michael Mandel, The Charter of Rights and the Legalization of Politics in Canada (Scarborough: Thomson Educational, 1987).

67. Brian Laghi, Campbell Clark, and Daniel Leblanc, "Martin hits hard at Harper: Liberal Leader uses second English debate to say he'd ban federal use of notwithstanding clause" Globe and Mail (January 10, 2006): A1.

68. Stephen Clarkson, The Big Red Machine: How the Liberal Party Dominates Canadian Politics (Vancouver: University of British Columbia Press, 2005). 